\title{
Uji Toksisitas Akut Ekstrak Spons Laut (Callyspongia aerizusa) terhadap Larva Artemia salina Leach dengan Metode Brine Shrimp Lethality Test
}

\author{
${ }^{1}$ Refrando M. Sondakh \\ ${ }^{2}$ Jimmy Posangi \\ ${ }^{2}$ Pemsi M. Wowor
}

\author{
${ }^{1}$ Program Studi Pendidikan Dokter Fakultas Kedokteran Universitas Sam Ratulangi Manado \\ ${ }^{2}$ Bagian Farmakologi dan Terapi Fakultas Kedokteran Universitas Sam Ratulangi Manado \\ Email: refrandosondakh@gmail
}

\begin{abstract}
Indonesia has a great potential of marine biological resources. One of the coral reef ecosystems is marine sponge Callyspongia aerizusa that contains compounds of steroid, alkaloid, flavonoid, and terpenoid. In order to develop those substances as components of drugs, it is necessary to perform initial screening of its acute toxicity potential. This study was aimed to obtain the acute toxicity potential of marine sponge extract using Brine Shrimp Lethality Test (BSLT). This was an experimental study using the posttest only control group design. Samples were 180 larvae of Artemia salina Leach divided into 6 groups of 10 larvae. Each group was tested with three replications. The marine sponge extract final concentrations in the media which contained larvae consecutively in groups $1,2,3,4,5$, and 6 were $1000 \mu \mathrm{g} / \mathrm{ml}, 500 \mu \mathrm{g} / \mathrm{ml}, 250 \mu \mathrm{g} / \mathrm{ml}, 100 \mu \mathrm{g} / \mathrm{ml}, 50 \mu \mathrm{g} / \mathrm{ml}$, and $0 \mu \mathrm{g} / \mathrm{ml}$ as the negative control. The observation was focused to larvae that died 24 hours after the administration of the extract. LC 50 value of the marine sponge extract was analyzed by using probit analysis with SPSS 16.0. The results indicated that the extract final concentrations that killed the larvae were $1000 \mu \mathrm{g} / \mathrm{ml}, 500 \mu \mathrm{g} / \mathrm{ml}$, and $250 \mu \mathrm{g} / \mathrm{ml}$. The result of probit analysis indicated that LC 50 value of marine sponge extract was $992.468 \mu \mathrm{g} / \mathrm{mL}$. Conclusion: The marine sponge extract had acute toxicity potential against Artemia salina Leach larvae according to BSLT with a LC 50 value $<1000 \mu \mathrm{g} / \mathrm{Ml}$.
\end{abstract}

Keywords: Acute toxicity test, BSLT, LC 50, Callyspongia aerizusa marine sponge

\begin{abstract}
Abstrak: Indonesia memiliki potensi sumber daya alam hayati laut yang besar. Salah satu ekosistem terumbu karang ialah spons laut Callyspongia sp. yang mengandung senyawa steroid, alkaloid, flavonoid, dan terpenoid. Diperlukan skrining awal mengenai potensi toksisitas akut untuk pengembangan bahan baku obat. Penelitian ini bertujuan untuk mengetahui potensi toksisitas akut ekstrak spons Callyspongia sp. menggunakan Brine Shrimp Lethality Test (BSLT). Jenis penelitian ialah eksperimental dengan posttest-only control group design. Hewan uji ialah 180 ekor larva Artemia salina Leach yang dibagi dalam 6 kelompok, masing-masing terdiri dari 10 ekor. Tiap kelompok dilakukan pengulangan percobaan 3 kali. Ekstrak spons laut diberikan dalam media yang berisi larva. Konsentrasi akhir ekstrak dalam media yang berisi larva berturut-turut dalam kelompok 1, 2, 3, 4, 5, dan 6 ialah $1000 \mu \mathrm{g} / \mathrm{ml}, 500 \mu \mathrm{g} / \mathrm{ml}$, $250 \mu \mathrm{g} / \mathrm{ml}, 100 \mu \mathrm{g} / \mathrm{ml}, 50 \mu \mathrm{g} / \mathrm{ml}$ dan $0 \mu \mathrm{g} / \mathrm{ml}$ sebagai kontrol negatif. Pengamatan dilakukan terhadap larva yang mati 24 jam setelah pemberian bahan uji. LC 50 ekstrak spons laut ditentukan dengan analisis probit menggunakan SPSS 16.0 for windows. Hasil penelitian menunjukkan beban konsentrasi ekstrak dalam media dapat membunuh larva secara berturut-turut dengan konsentrasi $1000 \mu \mathrm{g} / \mathrm{ml}, 500 \mu \mathrm{g} / \mathrm{ml}$, dan $250 \mu \mathrm{g} / \mathrm{ml}$. Hasil analisis probit menunjukkan nilai LC 50 dari ekstrak spons laut ialah $992,468 \mu \mathrm{g} / \mathrm{mL}$. Simpulan: Ekstrak spons laut menunjukkan adanya potensi toksisitas akut terhadap larva Artemia salina Leach menggunakan BSLT dengan nilai $\mathrm{LC}_{50}<1000 \mu \mathrm{g} / \mathrm{mL}$.
\end{abstract}

Kata kunci: toksisitas, BSLT, spons laut Callyspongia aerizusa 
Indonesia merupakan negara kepulauan yang besar di dunia yang memiliki wilayah laut yang sangat luas, dua pertiganya merupakan wilayah laut, Indonesia memiliki potensi sumberdaya alam hayati laut yang besar. Salah satu sumber daya alam hayati adalah ekosistem terumbu karang. Di dalam ekosistem terumbu karang bisa hidup lebih dari 300 jenis karang, lebih dari 200 jenis ikan dan berpuluh-puluh jenis moluska, krustasea, spons, algae, lamun, dan biota lainnya. ${ }^{1}$ Spons mampu menyaring bakteri yang ada di sekitarnya. Sebanyak $77 \%$ bakteri yang tersaring ini dicerna secara enzimatik dan mengeluarkan senyawa kimia hasil metabolisme yang dikenal sebagai metabolit sekunder berupa senyawa kimia yang memiliki kemampuan bioaktifitas yang bervariasi sesuai dengan masing-masing jenis spons. ${ }^{2,3}$

Callyspongia sp. merupakan salah satu jenis spons yang banyak tumbuh di perairan wilayah Indonesia. Isolat dari spons ini dilaporkan memiliki aktivitas antikanker, antimikroba, dan antiparasit. ${ }^{4}$ Callyspongia sp. ialah salah satu famili spons yang memiliki senyawa dengan bioaktivitas tinggi dan memiliki struktur permukaan tubuh yang berpori-pori sehingga dimasukkan kedalam filum porifera. ${ }^{5}$ Spesies ini merupakan salah satu biota laut yang memiliki kandungan berbagai metabolit sekunder diantaranya steroid, alkaloid, flavonoid, dan terpenoid yang ke depan dapat dimanfaatkan sebagai bahan baku obat. ${ }^{6}$

Penelitian ini bertujuan untuk mengetahui potensi toksisitas akut ekstrak spons Callyspongia aerizusa dengan Brine Shrimp Lethality Test (BSLT).

\section{METODE PENELITIAN}

Jenis penelitian ini ialah eksperimental dengan posttest-only control group design. Perlakuan dengan pemberian ekstrak spons laut terhadap larva Artemia salina Leach.
Bahan-bahan yang digunakan ialah ekstrak spons laut yang dimaserasi dengan, etanol 96\%, larva Artemia salina Leach, dan air laut.

Penetasan telur Artemia salina dilakukan dengan cara merendam sebanyak 50 mg telur Artemia salina dalam wadah berisi air laut di bawah cahaya lampu 40 Watt. Telur Artemia salina menetas dan menjadi larva setelah 24 jam. Larva Artemia salina yang baik digunakan untuk uji BSLT yaitu yang berumur 48 jam sebab jika lebih dari 48 jam dikhawatirkan kematian Artemia salina bukan disebabkan toksisitas melainkan oleh terbatasnya persediaan makanan.

Konsentrasi larutan uji untuk BSLT ialah $1000 \mu \mathrm{g} / \mathrm{mL}, 500 \mu \mathrm{g} / \mathrm{mL}, 250 \mu \mathrm{g} / \mathrm{mL}$, $100 \mu \mathrm{g} / \mathrm{mL}, 50 \mu \mathrm{g} / \mathrm{mL}, 0 \mu \mathrm{g} / \mathrm{mL}$ (sebagai kontrol negatif).

Pada uji toksisitas masing-masing konsentrasi dilakukan 3 replikasi dengan tiap kelompok sebanyak 10 ekor larva Artemia salina. Disiapkan wadah untuk pengujian[ untuk masing-masing konsentrasi ekstrak sampel membutuhkan 3 wadah dan 1 sebagai kontrol untuk masing-masing replikasi. Selanjutnya pada tiap konsentrasi larutan dimasukan 10 ekor larva Artemia salina, pengamatan dilakukan selama 24 jam terhadap kematian larva Artemia salina dimana setiap konsentrasi dilakukan 3 kali replikasi dibandingkan dengan kontrol. Kriteria standar untuk menilai kematian larva Artemia salina yaitu bila larva Artemia salina tidak menunjukkan pergerakan selama beberapa detik observasi.

Data hasil penelitian diolah dan disajikan dalam bentuk tabel. Data dari uji toksisitas dianalisis dengan analisis probit menggunakan SPSS 16.0 untuk menentukan nilai $\mathrm{LC}_{50}$.

\section{HASIL PENELITIAN DAN BAHASAN}

Hasil uji menunjukkan beban konsentrasi ekstrak dalam media dapat 
membunuh larva Artemia salina Leach secara berturut-turut hanya pada konsentrasi 1000,500 , dan $250 \mu \mathrm{g} / \mathrm{mL}$. Jumlah kematian larva Artemia salina Leach pada setiap gelas uji dalam berbagai konsentrasi perlakuan ekstrak spons laut ditunjukkan pada Tabel 1. Variasi konsentrasi ekstrak daun spons laut pada percobaan ini memperlihatkan pengaruh yang berbeda terhadap kematian larva Artemia salina Leach. Jumlah larva tiap gelas uji sebanyak 10 ekor, dan tiap konsentrasi dilakukan tiga kali pengulangan. Jumlah total larva $A$. salina Leach yang digunakan ialah 180 ekor larva. Larva yang digunakan berumur 48 jam karena pada umur tersebut anggota tubuh larva sudah lengkap dibandingkan saat larva menetas. Dalam mengamati pertumbuhan dan perkembangan larva sampai pada pengujian toksisitas ekstrak, digunakan alat bantu kaca pembesar.

Total kematian diperoleh dengan menjumlahkan larva yang mati pada setiap konsentrasi, sedangkan rerata kematian larva diperoleh dengan membagi total kematian larva pada tiap konsentrasi dengan jumlah replikasi yang dilakukan yaitu tiga kali. Kemudian dihitung persentase kematian larva dari rerata kematian pada tiap konsentrasi.

Respon kematian lebih besar terjadi pada konsentrasi $1000 \mu \mathrm{g} / \mathrm{mL}$. Hasil analisis probit dengan menggunakan SPSS menunjukkan harga LC50 dari ekstrak spons laut adalah $992.468 \mu \mathrm{g} / \mathrm{mL}$. Menurut metode BSLT menyatakan bahwa suatu ekstrak menunjukkan aktivitas ketoksikan dalam uji toksisitas jika ekstrak dapat menyebabkan kematian 50\% hewan uji pada konsentrasi $<1000 \mu \mathrm{g} / \mathrm{mL}^{6}$

Berdasarkan dari pernyataan tersebut maka ekstrak spons laut bersifat toksik. Hal ini ditunjukkan dari nilai LC50 yang diperoleh yaitu pada konsentrasi 992.468 $\mu \mathrm{g} / \mathrm{mL}$. Hal tersebut berkaitan dengan keempat senyawa yang terdapat dalam spons laut yaitu steroid, alkaloid, flavonoid, dan terpenoid dimana pada kadar tertentu memiliki potensi toksisitas akut serta dapat menyebabkan kematian larva Artemia salina Leach. ${ }^{7}$ Mekanisme kematian larva berhubungan dengan fungsi senyawa steroid, alkaloid, flavonoid, dan terpenoid dalam spons laut callyspongia sp. yang dapat menghambat daya makan larva. Cara kerja senyawa tersebut ialah dengan bertindak sebagai stomach poisoning (racun perut). Oleh karena itu, bila senyawa-senyawa ini masuk ke dalam tubuh larva, alat pencernaannya akan terganggu. Selain itu, senyawa ini menghambat reseptor perasa pada daerah mulut larva. Hal ini mengakibatkan larva gagal mendapatkan stimulus rasa sehingga tidak mampu mengenali makanannya sehingga larva mati kelaparan. ${ }^{8}$

Tabel 1. Pengaruh berbagai konsentrasi ekstrak spons laut terhadap Artemia salina Leach

\begin{tabular}{ccccccc}
\hline \multirow{2}{*}{ Replikasi ke } & \multicolumn{5}{c}{ Jumlah kematian larva tiap konsentrasi } \\
\cline { 2 - 7 } & 0 & $\begin{array}{c}50 \\
\mu \mathrm{g} / \mathrm{mL}\end{array}$ & $\begin{array}{c}100 \\
\mu \mathrm{g} / \mathrm{mL}\end{array}$ & $\begin{array}{c}250 \\
\mu \mathrm{g} / \mathrm{mL}\end{array}$ & $\begin{array}{c}500 \\
\mu \mathrm{g} / \mathrm{mL}\end{array}$ & $\begin{array}{c}1000 \\
\mathrm{~g} / \mathrm{mL}\end{array}$ \\
\cline { 2 - 7 } 1 & 0 & 0 & 0 & 1 & 3 & 5 \\
2 & 0 & 0 & 0 & 0 & 1 & 4 \\
3 & 0 & 0 & 0 & 1 & 2 & 5 \\
\hline Total kematian larva & 0 & 0 & 0 & 2 & 6 & 14 \\
Rerata kematian & 0 & 0 & 0 & 0,6 & 2 & 4,6 \\
\% kematian & 0 & 0 & 0 & 6 & 20 & 46 \\
\hline
\end{tabular}




\section{SIMPULAN}

Pemberian ekstrak spons laut menunjukkan adanya potensi toksisitas akut terhadap larva Artemia salina Leach yang ditunjukkan dengan harga $\mathrm{LC}_{50}<1000$ $\mu \mathrm{g} / \mathrm{mL}$ menurut metode BSLT.

\section{SARAN}

1. Perlu dilakukan identifikasi lebih lanjut terhadap jenis steroid, alkaloid, flavornoid dan terpenoid yang diduga berperan dalam toksisitas dari ekstrak spons laut Callyspongia aerizusa.

2. Perlu dilakukan penelitian lanjut tentang uji toksisitas dengan spesies spons callyspongia sp. yang lain.

\section{DAFTAR PUSTAKA}

1. Suparno. Kajian bioaktif spons laut (porifera: demospongiae) suatu peluang alternatif pemanfaatan ekosistem karang Indonesia dibidang farmasi [Makalah]. Bandung: Institut Pertanian Bogor; 2006.

2. Suharyanto. Distribusi dan persentase tutupan sponge (Porifera) pada kondisi terumbu karang dan kedalaman yang berbeda di perairan Pulau Barranglompo, Sulawesi Selatan. Biodiversitas. 2008;9:209-12.

3. Krisyuninda MP, Anurohim, Wahyudi A. Uji toksisitas fraksi spons Callyspongia sp dengan metode Brine Shrimp Test (BST) dari perairan Pasir Putih Situbondo. 2015. [cited 2017
Dec 16]. Available from: http://digilib.its.ac.id/public/ITSpaper-19992-paperpdfpdf. pdf

4. Hanni E, Munim A, Sekarini R. Identifikasi senyawa antioksidan dalam spons Callyspongia sp. dari Kepulauan Seribu. Majalah Ilmu Kefarmasian. 2005;2:127-33.

5. Sari NI, Ahmad A, Seniwati D. Isolasi dan karakterisasi protein bioaktif dari spons Callyspongia Sp. sebagai zat anti-oksidan. 2014 Feb 17. [cited 2017 Dec 16]. Available from: repository. unhas.ac.id/handle/123456789/8688/s how $=$ full.

6. Meyer BN, Ferrigni NR, Putnam JE, Jacobsen LB, Nichols DE, McLaughlin JL. Brine shrimp: A convenient general bioassay for active plant constituents. Planta Medica. 1982; 45:31-4.

7. Menggelea FP, Posangi J, Wowor MP, Bara R. Uji efek antibakteri jamur endosimbion spons laut Callyspongia sp. terhadap bakteri Pseudomonas aeruginosa dan Escherichia coli. eBm. 2015;3:376-80.

8. Cahyadi, R. Uji toksisitas akut ekstrak etanol buah pare (Momordica charantia L) terhadap larva Artemia salina Leach dengan metode Brine shrimp lethality test (BST) [Skripsi]. Semarang: Universitas Diponegoro; 2009. 